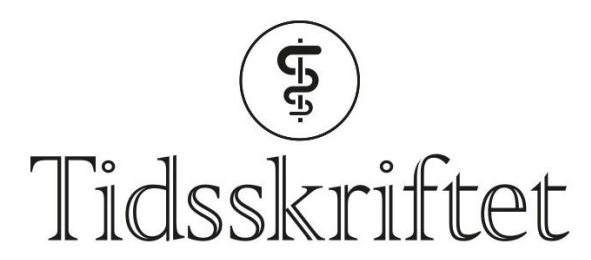

DEN NORSKE LEGEFORENING

\title{
Bruk ordet fosterantallsreduksjon
}

SPRÅKSPALTEN

\section{TILDE BROCH ØSTBORG}

E-post: tilde.ostborg@gmail.com

Tilde Broch Østborg er overlege ved Kvinneklinikken, Stavanger universitetssjukehus.

\section{ARIANE AUGESTAD}

Liv Ariane Augestad er ph.d., legevaktlege og førsteamanuensis ved Avdeling for helseledelse og helseøkonomi, Universitetet i Oslo. Hun arbeider med helseprioriteringer og måling av livskvalitet.

\section{MATHIAS BARRA}

Mathias Barra er ph.d. i matematisk logikk og seniorforsker ved Avdeling for helsetjenesteforskning $(\mathrm{H} \emptyset \mathrm{KH})$, Akershus universitetssykehus. Han arbeider med livskvalitetsforskning, matematisk modellering, helseøkonomi og bioetikk.

De siste årene har nyordet tvillingabort dukket opp for å beskrive det som oftest kalles fosterreduksjon. Vi argumenterer for at fosterantallsreduksjon er beste fagterm for inngrepet.

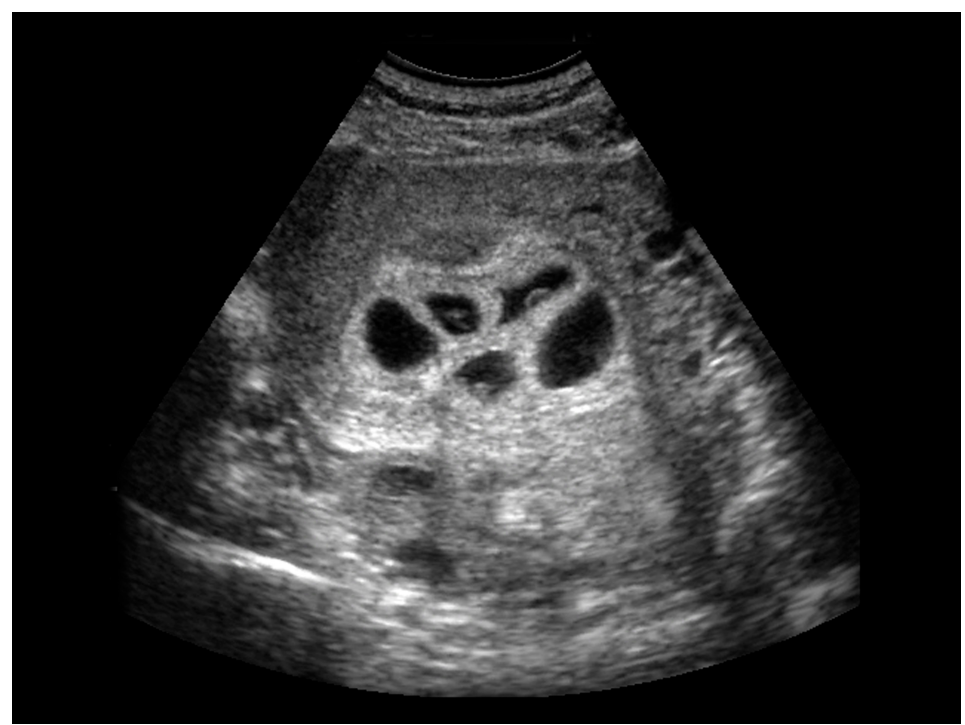

Illustrasjonsfoto: Science Photo Library / NTB Scanpix

Fosterantallsreduksjon utføres relativt sjelden i Norge (1). Ettersom prosedyren både er aktuell og kontroversiell, er det formålstjenlig med en nøytral og beskrivende begrepsbruk. Vi gjør her rede for hvorfor prosedyren bør benevnes fosterantallsreduksjon.

\section{Fosterreduksjon og tvillingabort er misvisende}

Fosterreduksjon er et uheldig og upresist begrep. Det er ikke størrelsen på et foster som reduseres (2), men antallet fostre i livmoren. Tvillingabort passer enda dårligere. Termen er 
upresis både fordi den bedre beskriver fullstendig avbrudd av et tvillingsvangerskap og fordi prosedyren også utføres ved svangerskap med flere enn to fostre i livmoren (3). I slike tilfeller blir prefikset tvilling direkte misvisende. NCSP-kodeverket har siden 2001 benyttet kodene MAJoo Reduksjon av fosterantall med ett foster og MAjio Reduksjon av fosterantall med mer enn ett foster $(1,4)$. Begrepet fosterantallsreduksjon er dekkende for begge situasjonene.

Det Norske Akademis ordbok har hatt fosterreduksjon som oppslagsord siden 4.2.2014, da det ble tatt inn etter en nyorddugnad (personlig meddelelse). Vi legger merke til at setningen som i ordboken illustrerer hvordan ordet brukes lyder "'fosterreduksjon' kan beskrives som en eufemisme. Finnes det noe bedre?». Noen argumenterer for at fosterantallsreduksjon er en eufemisme eller kan virke dehumaniserende $(2,5)$. En løsning kan da være å nytte abort ved fosterantallsreduksjon dersom konteksten gjør dette til et poeng.

\section{Bedre samsvar med andre språk}

Fosterantallsreduksjon samsvarer også godt med anbefalt engelsk benevning, multifetal pregnancy reduction $(6,7)$. Direkte oversatt blir dette flerlingsvangerskapsreduksjon, som også peker på at det ikke er et foster som reduseres, men et antall. Videre har Det Etiske Råd i Danmark i 2016 anbefalt termen fosterantallsreduksjon (8). Dette er det eneste stedet vi kjenner til at begrepet har vært behandlet innen vår språkfamilie.

Rådet for legeetikk og Legeforeningen sluttet seg til den danske anbefalingen i sine høringssvar om emnet i april 2019 $(9,10)$. Videre viser et søk i mediearkivet Retriever at fosterantallsreduksjon gir et tosifret antall treff i ulike medier og fagpresse. Også de som har vært kritiske til fosterreduksjon - både ordet og praksisen - ser ut til å foretrekke fosterantallsreduksjon (11).

Hovedproblemet er at ordet er langt og konsonantrikt, og det er mulig at fosterantallsreduksjon noen ganger vil forkortes til fosterreduksjon, særlig i tale. Dersom fosterreduksjon består som en kortform ved siden av fagtermen, synes vi likevel det vil være en forbedring i forhold til dagens situasjon.

\section{Nøytral og deskriptiv nomenklatur}

Vi foreslår at fosterantallsreduksjon heretter benyttes på norsk når noen, men ikke alle, fostre aborteres. Uavhengig av hvilke etiske eller medisinske betraktninger man gjør seg om inngrepet er alle tjent med en nøytral nomenklatur som er deskriptiv for prosedyren.

\footnotetext{
LITTERATUR:

1. Nasjonal behandlingstjeneste for avansert invasiv fostermedisin. Årsrapporter NSFM. Trondheim: St. Olavs hospital HF, 2019. https://forskningsprosjekter.ihelse.net/senter/rapport/NB-HMN-01/2018 Lest 4.6.2019.

2. Pedersen R. Om «fosterreduksjon». Dagens Medicin 11.2.2014.

https://www.dagensmedisin.no/artikler/2014/o2/11/om-fosterreduksjon/ Lest 7.4.2019.

3. Evans MI, Andriole S, Britt DW. Fetal reduction: 25 years' experience. Fetal Diagn Ther 2014; 35: 69-82. [PubMed][CrossRef]

4. Direktoratet for e-Helse. Prosedyrekodeverkene (Kodeverk for medisinske, kirurgiske og radiologiske prosedyrer, NCMP, NCSP og NCRP).

https://ehelse.no/standarder-kodeverk-og-referansekatalog/helsefaglige-kodeverk/prosedyrekodeverk ene-kodeverk-for-medisinske-kirurgiske-og-radiologiske-prosedyrer-ncmp-ncsp-og-ncrp Lest 4.5.2019.

5. Nortvedt P. Kan tvillingabort forsvares etisk? Sykepleien 2019; 107: e-76319.

6. Berkowitz RL, Lynch L. Selective reduction: an unfortunate misnomer. Obstet Gynecol 1990; 75: 873-4. [PubMed]

7. The American College of Obstetricians and Gynecologists' Committee on Ethics. Multifetal
} 
Pregnancy Reduction - ACOG.

https://www.acog.org/Clinical-Guidance-and-Publications/Committee-Opinions/Committee-on-Ethics /Multifetal-Pregnancy-Reduction Lest 1.2.2019.

8. Greisen G. Det Etiske Råds udtalelse om fosterantalsreduktion. København: Det Etiske Råd, 2016. http://www.etiskraad.dk/etiske-temaer/abort-og-fosterdiagnostik/publikationer/udtalelse-om-fostera ntalsreduktion-2016 Lest 4.6.2019.

9. Høring av forslag til endringer i abortloven - fosterreduksjon. Oslo: Rådet for legeetikk, 2019.

https://www.regjeringen.no/no/dokumenter/horing-av-forslag-til-endringer-i-abortloven-fosterreduk sjon/id2629710/ Lest 4.6.2019.

10. Høring - Forslag til endringer i abortloven - fosterreduksjon. Oslo: Den Norske Legeforening, 2019. https://beta.legeforeningen.no/hoeringer/interne/2019/forslag-til-endringer-i-abortloven-fosterreduks jon/hoeringsuttalelse/ Lest 4.6.2019.

11. Nortvedt P. Fosterantallsreduksjon er forskjellig fra selvbestemt abort. Sykepleien 3.5.2019.

https://sykepleien.no/meninger/innspill/2019/05/fosterantallsreduksjon-er-forskjellig-fra-selvbestemtabort Lest 6.5.2019.

Publisert: 21. oktober 2019. Tidsskr Nor Legeforen. DOI: 10.4045/tidsskr.19.0409

(C) Tidsskrift for Den norske legeforening 2020. Lastet ned fra tidsskriftet.no 